\title{
Mapping work-related stress and health in the context of the family firm
}

\author{
Sarah Drakopoulou Dodd
}

This is an author's post print of the paper published as:

Dodd, Sarah Drakopoulou. "Mapping work-related stress and health in the context of the family

firm." The International Journal of Entrepreneurship and Innovation 12, no. 1 (2011): 29-38.

\begin{abstract}
The family firm organizational form is an important element of even the most modern industrial landscape. The implications of family ownership and management of business enterprises for health and safety at work remain, perhaps surprisingly, unexplored. This study presents and illustrates several key organizational health and safety factors that are likely to be influenced by the family firm form. Special dangers include heightened risk of accident and poor physiological health. Special benefits are found to be higher task control, social support, evolutionary fitness and a richer accumulation of experiences. Additional research is recommended for this relatively unexplored area.
\end{abstract}

Keywords: family business; organizational health and safety; SMEs;

Examples of the workplace risks run by family business managers are staple ingredients of the news media. The suicide of German industrialist Dr Adolf Merckle highlights the specific and ultimate risks faced by family-firm members. 'The industrialist's friends and family blame his demise on a complex combination of pride, guilt over what he saw as failing his family, and, perhaps most importantly, loss of control,' the Daily Telegraph (2009) explained. The lawsuits that beset, for example, the Gucci family or the Hunt Petroleum Empire are indications of the emotionally intense conflict that can ferment within a family business.

Although few empirical data are available specifically studying this labour market group, 'anecdotal evidence has long suggested a high degree of chronic stress among the self-employed' (Jamal, 1997; see also Akande, 1994; Boyd and Gumpert, 1983; Yusuf, 1995). Jamal (1997) found that self-employed workers reported higher levels of stress and psychosomatic health problems than salaried employees. Whilst comprising just $7 \%$ of the US workforce in 2004, the self-employed made up $20 \%$ of workplace fatalities (Pegula, 2004). Recent Spanish evidence also shows that advanced organizational health systems are 'significantly less developed' in small than in medium-sized firms (Arocena and Nũnez, 2010, p 398). It thus appears that ${ }^{v}$ (small) business owner-managers are an especially vulnerable group in terms of occupational health and safety.

One of the principal elements in the SME environment is that of kin involvement in business ownership and management. The family firm remains a significant economic form across Europe and beyond, and is to be found not only within the SME sector - which it dominates. Many very large businesses indeed exhibit this ownership and management structure. The interactions between family and enterprise create very specific health, safety and stress factors, some of which may be seen to be generally positive, and others quite the reverse. Characteristics of the family firm that can be anticipated to reduce exposure to health and safety risks include strong organizational identity and engagement, plus heightened social support within the workplace. Dangers that are specific to the 
family firm comprise, inter alia, the transfer of domestic conflict to the working environment, kin rivalry and the taking of heightened risks to support one's family. It is perhaps surprising that this topic has received very little attention indeed, in spite of its clear importance.

The aim of this paper is to develop an initial, tentative mapping of work-related stress, health and safety in the context of the family firm. In so doing, I hope to provide a thorough and holistic review of work in the field, filling a gap in our current knowledge of family firms as working environments. Furthermore, the paper is intended to provide as solid as possible a foundation for future research by presenting a review of extant scholarship, by developing a suitable conceptual structure for framing new studies and by highlighting areas in which further research would be especially helpful. My research question, then, essentially asks how the nature and degree of work-related occupational health and safety issues are affected by the kinship context of family firms. The methodology used combines an extensive literature review with the development of a basic conceptual framework, and applies findings from family firm research to illustrate and underpin this model.

In line with common practice, I define a family firm as a business enterprise in which ownership control is held by two or more members of a family (or a partnership of families), in which there is clear strategic influence by family members on the management of the firm and there is a real concern for family relationships, and in which we can observe the dream (or the possibility) of continuity across generations. The study continues by presenting a simple model of occupational stress, noting its relevance for the wider issue of health at work, and then the model is applied to the family firm context. Special attention is paid to the family firm owner-manager. Finally, conclusions are drawn and recommendations for practitioners, policy makers and researchers are proposed.

\section{A simple model of occupational stress}

The core concepts of psychological approaches to explaining occupational stress and its impact on health are presented in a simplified model in Figure 1. A variety of stressors have the potential to produce negative health outcomes for workers, which range from their being more likely to have an accident, or more susceptible to heart disease or to higher rates of sickness. The nature and degree of these health outcomes are mediated by individual differences - such as personality traits, resilience and so forth - which also shape the impact and suitability of coping strategies. One man's stressor may be another man's engaging challenge.

Stressors can be categorized as relating to one's occupational role, being intrinsic to the specific job, deriving from an occupational environment or stemming from the home-work interface. The following discussion will examine the four main elements of this model - stressors, individual differences, coping strategies and the consequences of distress - from the perspective of the family firm. It is hoped that, by bringing empirical findings and conceptual developments from family firm research into the structure of the occupational stress model, it will be possible to identify and to begin to analyse this underexplored area. Rather than attempting to concentrate on a wide range of family firm stakeholders, the subsequent discussion concentrates on family firm owner-managers, or the incumbent CEO. This role embodies the nexus of family and firm interactions, and also permits some focus and depth in the subsequent analysis. It is recognized that this is a limitation of the present study, and it is noted that there is a substantial research gap in the field, of which this paper can tackle only a small subset. 


\title{
Figure 1: A simple model of occupational stress and health
}

\author{
Coping \\ Strategies
}

\begin{tabular}{|c|c|}
\hline \multicolumn{2}{|c|}{ Stressors } \\
\hline $\begin{array}{l}\text { Role-related } \\
\text { stressors }\end{array}$ & $\begin{array}{ll}\text { - } & \text { Role conflict } \\
\text { - } & \text { Role ambiguity }\end{array}$ \\
\hline $\begin{array}{l}\text { Stressors } \\
\text { Intrinsic to the } \\
\text { Job }\end{array}$ & $\begin{array}{l}\text { - Psychosocial Aspects } \\
\text { - Task control }\end{array}$ \\
\hline $\begin{array}{l}\text { Organizational } \\
\text { environment } \\
\text { stressors }\end{array}$ & 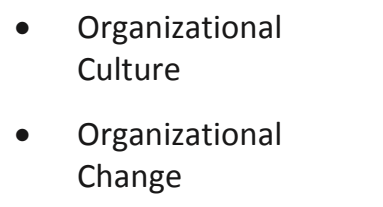 \\
\hline $\begin{array}{l}\text { Home-work } \\
\text { interface }\end{array}$ & $\begin{array}{l}\text { - } \quad \text { Time-based conflict } \\
\text { - Role behaviour } \\
\text { conflict }\end{array}$ \\
\hline
\end{tabular}

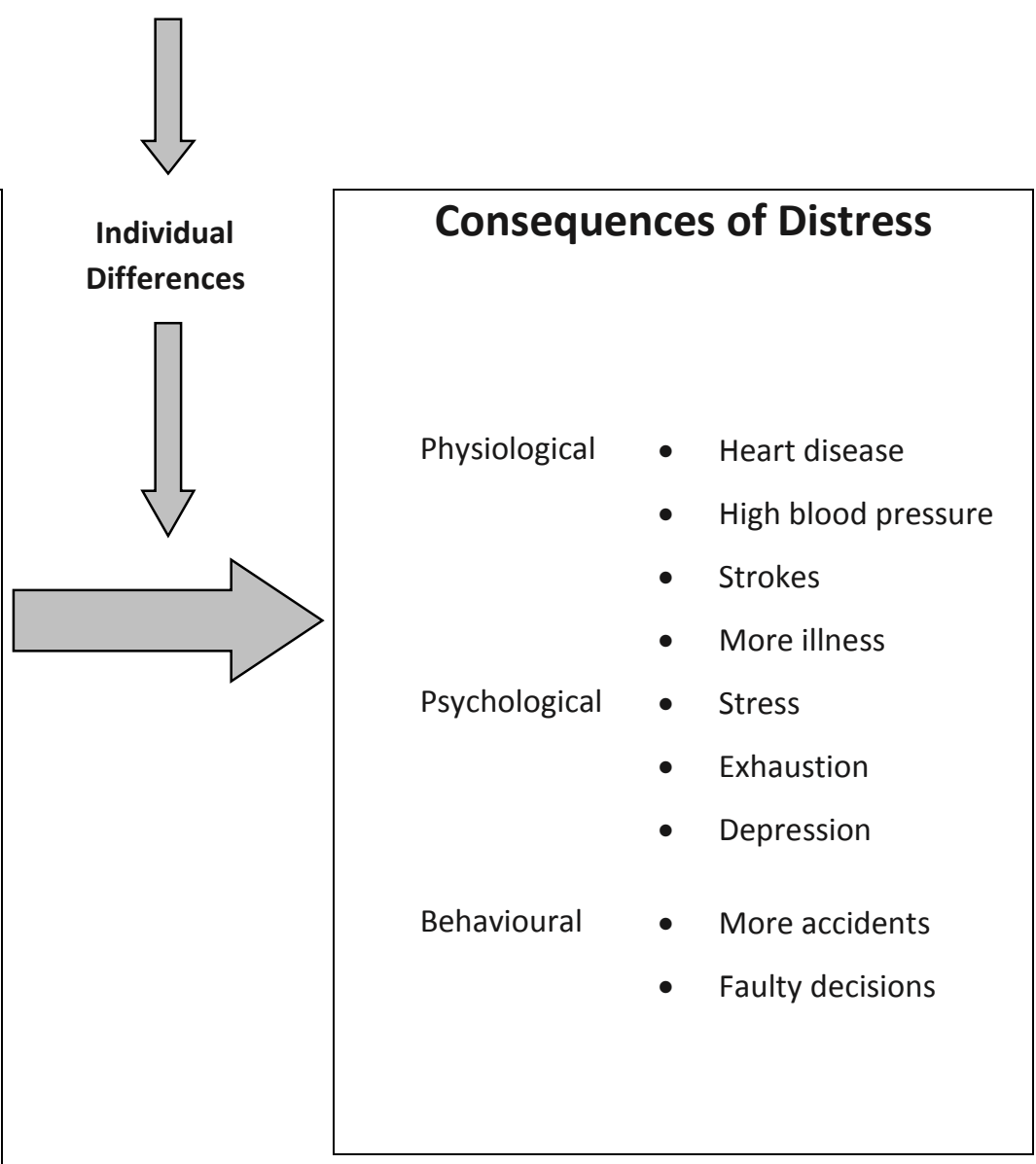

Adapted from Clarke and Cooper 2000 p 175 and McShane and Von Glinow 2008 p 200

Although very little is known about family firms and stress, there is a small body of work that examines occupational health issues relating to the entrepreneur. Such work, where relevant and helpful in illuminating the family firm owner-manager's situation, is also used in the subsequent analysis. It can be summarized thus: 
'There is evidence that business owners have a lot of stressors in their work. For example, entrepreneurs work longer than non-entrepreneurs...and have more role conflict and role ambiguity.... However, empirical evidence suggests that entrepreneurs perceive less

stress than non-entrepreneurs.' (Rauch et al, 2007, p 101)

\section{Stressors}

\section{Role-related stressors}

Role-related stressors in the workplace are typically seen to derive from some form of conflict about the individual's work role or ambiguity around the role, which generates anxiety. In one of the few relevant empirical studies to date, Buttner (1992) did indeed find that, for entrepreneurs, role conflict was lower than for comparable managers, since entrepreneurs have more control over the roles that they create for themselves within their own ventures.

Buttner's study, however, showed that for entrepreneurs, role ambiguity was higher than for comparable managers, and that this was related to higher levels of stress. For entrepreneurs, such ambiguity centres around the multiple roles that are demanded of them (salesman, leader, engineer, etc) and uncertainty about how much authority is expected of them. Feltham et al (2005) found that for the family firm, very high levels of dependence on a single decision maker were reported. Feltham et al also reported that most family firm leaders were making decisions across many of the five main managerial functions. The potential for high levels of role ambiguity also appears to be present for family firm entrepreneurs. However, the authors found that these multiple roles were well understood by the decision makers themselves, as well as by the family. It seems that family firm leaders may be very clear indeed about the responsibility that their role entails. The conditions for role ambiguity exist within the family firm, but - unlike in the general population of entrepreneurs - it appears that role clarity is enjoyed.

\section{Stressors intrinsic to the job}

Not all jobs are stressful in the same way or to the same degree. Beyond environmental factors common across specific organizational sectors - such as the risk of violence encountered by small shop owners - job types may also exhibit characteristics that have been shown to generate stress. Among these intrinsic, job-specific potential stressors are psychosocial aspects of the job, as well as an individual's task control.

Psychosocial stress. Psychosocial aspects of the workplace that can act as stressors include long working hours, competing demands on time and attention, plus job-specific anxieties such as lack of status or economic worries. The nature and degree of psychosocial stressors vary by job type and organizational sector (Clarke and Cooper, 2000, p 174). For example, long hours are an important psychosocial stressor for many occupational groups, but appear not to be so for the self-employed, perhaps because they can control their own time to a greater degree (Taris et al, 2008).

In order to highlight the potential relevance of psychosocial stressors for family firms, the farming sector has been utilized as an exemplar, since this is one of the few sectors studied that is largely populated by familyowned and managed ventures. Farms are among the most dangerous workplace environments, and have been much studied. Farms are also, of course, very often family firms, and the deep emotional connection between land and family is one of the best examples of the affective ties between clan and enterprise. A recent Danish study investigated the impact of psychosocial stress on farming accidents; among the potential psychosocial stressors studied were psychological work demands on time and attention; workload; interruptions; and economic anxieties (Glasscock et al, 2006). All of these stressors were found to be correlated with workplace accidents and, importantly, 'economic worries were seen to be directly related to injury' (Glasscock et al, 2006 $\mathrm{p}$ 185). It is plausible to argue that the dangerous pressures of economic responsibility for the family's well-being are unlikely to be unique to the farming sector. 
Task control. An additional potential workplace stressor type is that encountered by people who have very little control over their work. Generally within the family firm, a great deal of autonomy is experienced by the owning/managing family, and thus task-control stressors are unlikely to be substantial. These results are consistent with those for the self-employed, among whom more authority over the decision-making process is enjoyed (compared with employees), with positive health benefits (Parslow et al, 2004). Indeed, there is some evidence that even more autonomy and higher performance are demanded of family member employees, and that these result in greater job satisfaction and organizational commitment (Beehr et al, 1997, p 308). Note that the same results were not obtained for nonfamily employees in family-owned firms, who may indeed suffer a range of stressors as a result of preferential treatment of family members.

\section{Organizational environment stressors}

Beyond the individual's job, the wider organizational environment can also be a source of stressors. Such workplace 'toxicity' can be generated by certain organizational cultures, by the strains of organizational change, or by the nature of the material environment of the business. To what degree can family firm specific stressors be uncovered within the organizational environment?

Organizational culture. Recent evidence (Zahra et al, 2008) suggests that organizational culture plays an even greater role in family firms than in non-family ones. The impact of organizational culture as a generator - or mitigator - of stress is, following this line of argument, likely to be amplified within the family firm. One of the most compelling recent theoretical analyses of the family firm is that which draws upon the neo-Darwinian perspective of evolutionary psychology. There is a very strong argument to be made that human psychology is specifically evolved to 'fit' within the family firm environment. Human beings first started carrying out specialized productive tasks, beginning with farming and hunting and then moving on to the manufacture of clothing, shelter, weapons, jewellery and so forth. All these early enterprises were based upon the family as a productive unit. Working alongside one's family is an ancient tradition, perhaps even a 'natural' activity, given that we evolved as social animals in highly collaborative kinship groups.

Nicholson (2008, p 104) argues that 'the endurance and continuing popularity of family firms are due to their closeness in certain respects to the primal models to which our evolved psychology is particularly fitted'. We are built to work in kinship groups. This may be why career satisfaction, personal advantage and organizational commitment tend to be higher for family firm member-employees than for other types of employees (Beehr et al, 1997, p 306). Nicholson and Gordon (2008, p 8) provide a very evocative description of the positive side of family firm culture, writing of 'the love, commitment, trust and confidence of people who know each other intimately.... [that] makes people go the extra mile for each other, and enables them to voice problems and solve them with great directness...creating a special sense of solidarity and community'. The longer-term perspective, specialized knowledge, heightened commitment, patient capital, sustained values and continuity, which are associated with the family firm, also form a positive organizational cultural nexus (see, for example, Carney, 2005).

The culture of family firms is not, of course, homogeneous in nature, and within the wider family firm sector, several distinct subcultures have been proposed. Some of these less collaborative, more combative cultural forms can - especially by transferring family conflict into the business - act to create toxic cultures that are damaging to all who are exposed to them. The sorry tales of family wars, suicide, business collapse, personal misery - and even homicide - provide the most vivid example possible of environmental workplace stressors with negative health outcomes. This important topic has been discussed extensively in the family firm literature and will be summarized below.

Organizational change. Organizational change is a major stressor within the workplace environment, and the more dramatic the change, the more pronounced the stress is apt to be (Härenstam et al, 2004). Miller et al (2008, pp 57-59) set out a 'stewardship view' in which continuity, command and control were understood to provide positive strategic coherence to family firms. In larger, older firms, renewal-restricting variables include 'change-resistant family factions, owners with cronylike associations with governments, and owners who have become entrenched, exploitative of other shareholders, and remote from day-to-day operations' ( $p$ 57). For 
smaller firms, renewal is restricted by a lack of resources, conservatism, a reluctance to grow, and their short life ( $p$ 70).

Conversely, some family firms have been found to have cultural preferences for entrepreneurship (Zahra et al, 2008). Craig and Moores (2006, p 7) provided evidence that 'family firms appear to place substantial importance on innovation practices and strategy'. Carney (2005) has argued forcefully that the personalism and particularism associated with the family firm form enhance rapid and flexible opportunistic investments based on intuitive heuristics. Concentration of control in family hands may facilitate organizational renewal by removing any potential outside interference (Miller and Le Breton-Miller, 2006). However, since this propensity to change is inherent in the culture of the firm and in the hands of the managing family, it may well prove to be an engaging challenge rather than an externally imposed perceived threat.

In summary, empirical evidence suggests that family firms experience both very specific inhibitors and facilitators of organizational change. Indeed, it is precisely this strong stewardship commitment to the family firm that has been found to facilitate strategydriven change: 'a strong family culture committed to the family firm is conducive to strategic flexibility' (Zahra et al, 2008, p 1047). This intertwining of stewardship and strategic flexibility may provide a solid change narrative, a foundation of cultural continuity and a sense of 'change ownership' that mitigate the negative strain associated with organizational change.

\section{Home-work interface}

The modern private/public divide is not much in evidence within family firms. Indeed, connections between family and enterprise are multiplex, dynamic and varied (Miller and Le Breton-Miller, 2006; Zahra, 2005). What evidence is there of time-based conflict and/or role behaviour conflict acting as stressors within the family firm?

Time-based conflict. Some scholars have viewed the interaction between domestic and career environments as a competition for limited resources (such as time), which generate stress (Greenhaus and Beutell, 1985). For others, however, the psychological enrichment that comes from multiple roles potentially far outweighs such stress (see, for example, Grzywacz et al, 2007; and Sieber, 1974). There is indeed substantial empirical evidence that such role enhancement acts to improve (among other things) health (Waldron et al, 1998), provided that roles are perceived to be of high quality.

Buttner (1992) did not find that role overload - working very long hours enacting an entrepreneurial role - led to more health problems. Jamal (1997) reported similar findings, noting that 'the sum of the positive experiences in a role outweighs the negative experiences...it has been suggested aspects of a work role may actually increase energy levels when there is a high demand for personal energy needed in the job'. So the long working hours demanded of family firm entrepreneurs, plus the expanded roles associated with this, may in fact be enhancing positive experiences, increasing energy levels and mitigating stress and strain.

Role behaviour conflict. As Beehr et al argue, family firms may be especially susceptible to inter-role conflict, because so many people involved will be related to each other in two quite different roles, as parents and as managers, for example:

'From a role theory point of view, people in ... family business might be expected to be especially susceptible to interrole conflict, because they are involved in two role systems that both overlap and complete (the family and the business).' (Beehr et al, 1997, p 298)

Indeed, the family firm literature highlights the significance of this behaviour-based conflict, which can impact upon the emotional, psychological and physiological well-being of family firm owners, managers and employees. Specific family-related conflicts that can spill over into the business include divorce, intergenerational conflict between parents (especially fathers) and their children, plus issues caused by the loosening of kin ties as generations pass. Sibling rivalry is also an issue, particularly related to the succession of the CEO role, nepotism, jealousy, exploitation, sentiment and overemotional decision making: these are all potentially disastrous 
stressors that can create conflict of the most damaging kind within the family firm (Nicholson and Gordon, 2008, p 8). Danes (2006) found that work/ family balance (together with justice issues) was the biggest tension producer for both spouses working in family firms. Kets de Vries et al (2007, p 109) point out that: 'the driving forces of narcissism, sibling rivalry, envy and family myths can be very powerful indeed...dysfunctional entanglements may occur, with devastating results'. Such conflict has profound significance for the mental and physical health of all in the workplace, most especially family members. Similarly, conflict can stem from the dramatic personal and intergenerational impact of the shame associated with entrepreneurial failure, and of anxieties around perceived potential failure (see Smith and McElwee, 2011, for a thorough analysis of entrepreneurial shame).

Yet, although its consequences can be dire, it does not seem empirically that such workplace stress is common. One of the rare comparative surveys on this topic was that carried out by Beehr et al (1997). Their empirical study was unable to establish a statistically significant difference between 'the groups of family and non-family members and people in family and non-family businesses' in terms of behaviour-based (inter-role) conflict (Beehr et al, 1997, pp 305-306). Their findings also showed that the impact of conflict upon these groups was very similar. Overall, the authors concluded that: 'rather than problems...the empirical evidence...suggests that it is more likely that some benefits arise from this dual status' (Beehr et al, 1997, p 310). An additional benefit for family firm members, protecting them from stress, illness and accident, can be found in recursivity between domestic and work environments. Due to the permeability of barriers between the domestic and business domains for family firm members, such effects are likely to be amplified. Here, a virtuous circle of positive experiences and behaviours can reinforce both contexts and the roles played within them:

'positive experiences at work... spillover and promote more caring and generative behavior in the family, which accumulate over time and contribute to flexibility and resilience in the family...likewise, positive experiences in the family spillover and promote more caring and generative behavior in the workplace and shape the way workers interact with each other and their clients.' (Grzywacz et al, 2007, p567)

Although business performance is not within the remit of the current study, it is also worth noting that such positivity and flexibility have been associated with strong long-term business performance (for example, Losada, 1999). This in turn enhances intrinsic and extrinsic rewards, both of which - satisfaction and financial well-being - are important for health.

\section{Individual differences}

Buttner's (1992) survey found that individual differences - such as personality type - did not have a direct impact upon health and satisfaction outcomes for entrepreneurs. However, personality type was found to mediate or moderate the relationship between stressors and health outcomes for the entrepreneurs in the sample. Specifically, type A personalities did not seem to find that role ambiguity generated stress and negative outcomes, whereas type B personalities did experience these workplace health problems. Another personality trait that has been associated with lowering the impact of stressors on health is internal locus of control. It is also worth noting that employees who are type A individuals (and those with higher internal locus of control) have quite consistently been found to be more likely to be involved in accidents. However, this finding has not been reproduced for the self-employed. Specifically, the authors of a study into self-employed Danish farmers were surprised to report 'the inability of the present study to replicate previous findings with safety locus of control and type-A behaviour, neither of which were related to accidental injury' (Glasscock et al, 2006, p 183).

A substantial issue for many firms is that, due to the impact of homophily on employee selection, development and promotion, managerial teams end up being populated by people who exhibit very similar personal traits. Clusters of people with the same traits have less likelihood of diversity in coping with various kinds of stress. Interestingly, and perhaps surprisingly, individual differences are enhanced within a family firm by the variances inherent in genetic selection: 'the gene lottery dictates that family groups will display more diversity than one regularly finds in business teams' (Nicholson, 2008, p 109). 


\section{Coping strategies}

A variety of strategies has been suggested by which people cope with stressors, minimizing their negative impact upon health and mental well-being. Of special relevance to this examination of the family firm environment are the following coping strategies: buffering through social support, distancing and detachment, and exercise.

Social support. Social support has been shown to mitigate the impact of stressors upon health, acting as a buffer in some instances and providing a direct positive impact on well-being in others (Seers et al, 1983, Viswesvaran et al, 1999). Quantity, and sometimes quality, of social support has been correlated with a very wide range of health issues, even including mortality (House et al, 1988). The family firm environment provides a network of highly supportive social relationships, extending emotional support, interest and engagement beyond the domestic sphere and into the workplace. As such, it can be anticipated to provide very positive facilitators of good health and psychological well-being to those employed in such an environment.

Distancing and detachment. Another classic coping mechanism for relieving stress consists of removing oneself from the context and the relationships in which such stress is occurring (distancing). Although long hours seem to have a positive effect on the engagement, satisfaction and well-being of entrepreneurs, this is not so for continued psychological engagement with matters relating to the firm (Buttner, 1992; Taris et al, 2008). For the family firm, however, workplace colleagues and stressors literally come home with the individuals, removing the possibility for this coping strategy to be implemented (Beehr et al, 1997, p 298). Involvement in a business venture with other family members essentially inhibits the likelihood that time away from work will be spent in some form of detached recovery from the stresses of the working environment.

Exercise. Another frequently recommended coping strategy is exercise, which has also frequently been recommended for the entrepreneur (Goldsby et al, 2005, p 79). The impact of physical fitness on reducing sickness, stress and lowering mortality rates is well documented. Given the emotional involvement of the family with the managing entrepreneur, there are further incentives for protecting the physical well-being of family firm leaders and taking every opportunity to encourage strategies that are likely to extend their lives. Goldsby et al (2005, p 84) provide empirical evidence of the effectiveness of this coping strategy, both for the entrepreneur and the business: 'entrepreneurs who regularly run were better at attaining personal satisfaction, independence, and autonomy. Their companies also indicate significant improvement in sales over companies managed by nonrunners.' Since family firm leaders often prioritize the firm's well-being over their own, the positive impact of exercise upon the health of both business and individual is important.

\section{Consequences of stress}

The consequences of stress can be categorized as physiological, psychological and behavioural in outcome, and there are instructive insights to be gathered from a review of data pertaining to entrepreneurs, considered from a family business management perspective.

Physiological. The physiological outcomes of stress include ailments related to high blood pressure, heart disease, strokes and a propensity to fall ill more easily and often. Other material health problems that can stem from workplace stress include chronic back and head pain and sleeping difficulties. Goldsby et al (2005, p 89) note that the literature to date has found that 'a majority of entrepreneurs who were studied had back problems, indigestion, insomnia, or headaches'. Buttner's (1992) study of entrepreneurs and managers examined more than 30 health issues associated with workplace stress, which included 'headaches, insomnia, loss of appetite, backaches, ulcers, and indigestion experienced in the past six months'. Buttner then created a scale using the severity and frequency with which this range of ailments had been experienced by respondents. The (1992) study found that entrepreneurs reported much higher levels of health problems than managers: whereas managers were calculated to have a summary health score of 19.3, for entrepreneurs this figure was 38.7.

Goldsby et al argue that entrepreneurs may be seen to accept these negative outcomes as part of the price for success. This is consistent with Rauch et al's (2007) findings, which showed a correlation between the business survival of entrepreneurial firms and higher levels of psychosomatic ailments reported by entrepreneurs. 
Family firm chief executive officers hold their position on average for 25 years, compared with just five years for non-family CEOs. The burdens of entrepreneurial leadership thus fall squarely on their shoulders for much of their working life, so these additional health implications may be anticipated to be a serious problem. An important issue here is likely to be the degree to which these problems are mitigated by the coping strategies inherent in the family firm - such as the buffering provided by social support. However, data are not available to address this question, which surely merits further investigation.

Psychological. The general connection between workplace stress and serious psychological problems is well established, as Ercolani (2008) has highlighted. Such problems include depression, acute anxiety and exhaustion. No empirical examinations of these conditions amongst family firm samples were discovered through the literature search methodology utilized in this study. A brief presentation of work relating to the selfemployed is thus utilized instead. Some arguments have been made to suggest that heightened decision authority/ task control, work engagement and autonomy will reduce the likelihood of psychological ill health for the selfemployed (Parslow et al, 2004). However, empirical studies find no difference between the self-employed and employed in terms of mental health measures (such as depression and anxiety) in spite of the more satisfying work that the self-employed report. Jamal (1997) also could not differentiate between the self-employed and employed samples in his study in respect of the prevalence of mental health issues. It seems plausible that the positive impact of task control and engagement for the self-employed may be offset by the strains associated with entrepreneurship, which, as we have seen, result in worse physical health. It is interesting, however, that although apparently experiencing poorer physiological well-being than other occupational groups, the selfemployed do not appear to enjoy worse mental health. Family firm managers and members enjoy - as we have seen - the additional benefits of social support and evolutionarily appropriate organizational cultures.

Behavioural. Negative consequences of distress that are generated by behaviour typically include more accidents and faulty decision making. There is some evidence that this is a particularly important issue for the family firm.Pegula (2004) concludes, from his study of 2001 US workplace fatalities, that the self-employed are vastly overrepresented in this group, with $20 \%$ of fatalities at work, whilst comprising just $7.4 \%$ of the workforce. He argues that there are multiple reasons for this, including the nature of the sectors in which the self-employed work (such as farming, small retail shops and construction), the long hours they work, their greater age and the risks they are prepared to accept. Pegula (2004, p 34) also found that homicide and suicide rates for the selfemployed were much higher than those for employed workers in the same sectors, as were accidents such as overturning a tractor. The socioeconomic implications of self-employment in certain sectors also increase danger to these small-scale entrepreneurs. Pegula infers that:

'small "mom-and-pop" retail establishments may be more attractive to robbers because security is likely to be less than in other stores. Self-employed farmers might have to make do with unsafe equipment or may simply ignore safety concerns in order to stay competitive.' (2004, p 35)

Although Pegula's research concentrated on the self-employed, it should be noted that the factors he discovered to be especially relevant in explaining workplace fatalities are those that are strongly associated with the family firm. Small shops, farms and construction sectors are all dominated by family firms, for example. Long hours and substantial risks are also justified within the family firm environment as being a special commitment to the family's socioeconomic wellbeing. This is reinforced by the innate drivers of evolutionary psychology, in which 'the family is the primary mechanism for the transmission of identity beyond one's lifespan' (Nicholson, 2008, $p$ 105), generating enhanced force for sacrificing oneself for the family firm. Unfortunately, it seems that this may only too frequently become a quite literal sacrifice, with family firm owner-managers laying down their lives in the service of the business.

This potential for physical risk appears to be a correlate of the family firm strategic risk. When the family firm is in commercial jeopardy, business-owning families can react with either very risky or, conversely, very risk-averse strategic behaviours, depending upon which is most likely to protect the socio-emotional wealth invested within their ventures (Gómez-Mejia et al, 2007). It seems that, when necessary, family firm members can also engage in very risky behaviours that go beyond the strategic, to include risks to health and life. 


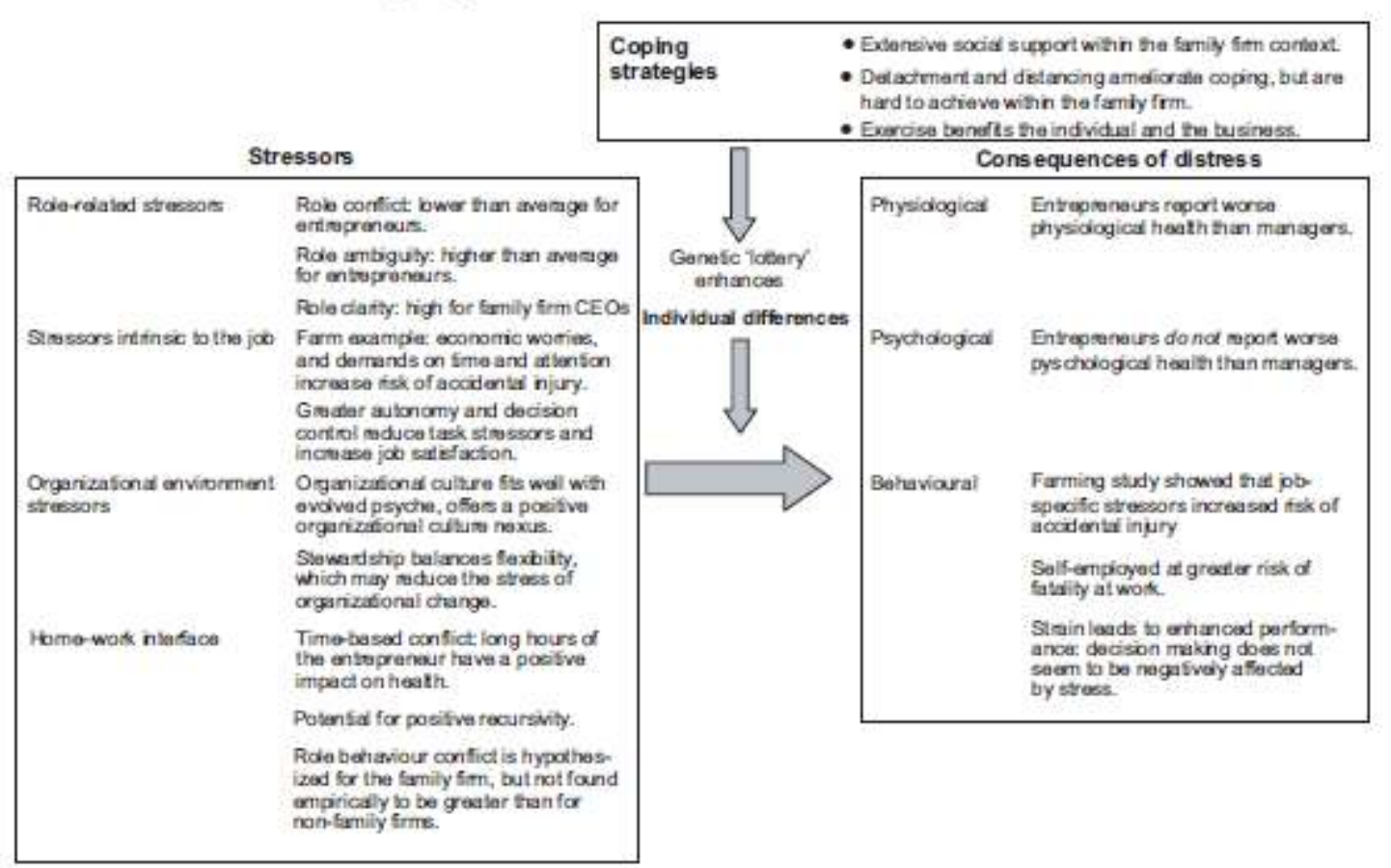

Figure 2. Occupational stress in the family firm.

\section{Conclusions}

The aim of this study is to develop an initial, tentative conceptualization of health and safety at work within the family firm context. Special attention is paid to the family firm owner-manager. The significance of family firms in even the most modern industrial environment has been established and their special importance in the SME grouping underlined. A simple model of occupational stress and health has been presented and applied as the framework for this analysis. Family firm data and theory have been used wherever possible, supplemented by material relating to the self-employed or the entrepreneur, where necessary. Figure 2 illustrates the findings of this review within the framework of the organizational stress model.

With regard to stressors, role conflict appears to be low for entrepreneurs, whilst role ambiguity may be higher than for comparable managers. Family firm entrepreneurs, by contrast, appear to be very clear as to their roles, in spite of the multifunctional nature of their decision authority. The farming sector, symbolic 'home' of the family firm, showed that psychological demands on attention and time could be correlated with greater chance of workplace injury, and that economic anxieties represented a special danger. The high task control and decision autonomy of the self-employed reduce the incidence of psychosocial stressors related to the lack of such freedom in the workplace. Indeed, family firm member employees reported greater autonomy and the challenge of higher performance demands, which in turn created greater job satisfaction. Arguments from evolutionary psychology were utilized to propose that the family firm represents an environment to which we are particularly suited, or 'fitted'. The 'stewardship' culture of family firms generates a comforting continuity, whilst entrepreneurial culture promotes an engaging and challenging flexibility. Thus the stressors generated by organizational change are less likely to be experienced in a negative fashion within the family firm environment, especially given the family's control over decisions relating to the change process. Although entrepreneurs work very long hours, this does not seem to impact negatively upon their health, rather acting as an accumulation of rich experiences, which generates overall well-being. 
It is within the sphere of inter-role relationships that family firm specificities are the most pronounced. The dramatic conflict that is the dark side of family firms is generally related to some form of family emotional crisis. Outcomes of such conflict can be violent, even fatal. However, there appears to be no overall greater tendency for family work inter-role conflict within family firms, and indeed, positive spillovers between environments have been argued to create virtuous circles of support, positive affect and resilience.

In terms of individual differences, the genetic lottery seems to generate more divergence between family firm leading kin groups than is the case when choice drives managerial selection. Coping strategies of special relevance for family-owned businesses include social support, for which family firms are especially well suited, and detachment, for which they are not. Exercise appears to be another suitable coping strategy for family firm managers.

Family firm owner-managers can be argued to exhibit heightened exposure to accidents and fatalities due to a variety of causes such as the type of industrial sector, longer working hours, greater age and higher selfselected exposure to risk. Whilst entrepreneurs in general report worse physiological health than other control groups, this is not so for psychological health. However, one study has shown that the greater the strain experienced by the entrepreneur (measured as the occurrence of psychosomatic complaints), the higher the chances of longterm survival for their business (Rauch et al, 2007). Perhaps some trade-off between personal and business health is accepted by the entrepreneur, particularly if kin altruism is motivating such sacrifice within the context of the family firm.

Limitations of this study include its focus on family firm CEOs; clearly, other family firm stakeholders, including successors, spouses and non-family employees, also merit investigation. The survey methodology utilized has also hampered a deeper investigation of some potentially important areas, although it is hoped that these have at least now been flagged up for study. Furthermore, it proved necessary at times to 'borrow' material from the wider SME and entrepreneurship literature, due to lack of family-firm-specific scholarship, which is clearly not an ideal scenario. Nevertheless, the study has indicated that the family firm is a rather idiosyncratic workplace, from an occupational health and safety (OHS) perspective. It exhibits special dangers - such as heightened risk of accident and poor physiological health - and special benefits - such as higher task control, social support, evolutionary fitness and a richer accumulation of experiences. Given these family-firm-specific elements and the overall importance of family firms to the wider environment, it seems clear that much further research in this area is merited.

\section{Acknowledgments}

This report was funded by the Health at Work project. The lead partner for this project is the Centre for European Labour Market Research (CELMR), University of Aberdeen Business School. The project is supported by the European Commission through the Seventh Framework Programme 'Health 2007 A'. 


\section{References}

Akande, A. (1994), 'Coping with entrepreneurial stress: evidence from Nigeria', Journal of Small Business Management, Vol 32, pp 83-87.

Arocena, P., and Nũnez, I. (2010), 'An empirical analysis of theveffectiveness of occupational health and safety management systems in SMEs', International Small Business Journal, Vol 28, No 4, pp 398-419.

Beehr, T. A., Drexler, J. A. Jr, and Faulkner, S. (1997), 'Working in small family businesses: empirical comparisons to non-family businesses', Journal of Organizational Behavior, Vol 18, No 3, pp 297-312.

Boyd, D. P., and Gumpert, D. J. (1983), 'Coping with entrepreneurial stress', Harvard Business Review, Vol 61, No 2, pp 44-64.

Buttner, E. H. (1992), 'Entrepreneurial stress: is it hazardous to your health?' Journal of Managerial Issues, Vol 4, No 2, pp 223-240.

Carney, M. (2005), 'Corporate governance and competitive advantage in family-controlled firms', Entrepreneurship Theory and Practice, Vol 29, pp 249-265.

Clarke, S. G., and Cooper, C. L. (2000), 'The risk management of occupational stress', Health, Risk \& Society, Vol 2, No 2, pp 173-188.

Craig, J. B. L., and Moores, K. (2006), 'A 10-year longitudinal investigation of strategy, systems, and environment on innovation in family firms', Family Business Review, Vol 19, No 1, pp 1-10.

Daily Telegraph (2009), Website: http://www.telegraph.co.uk/ finance/financetopics/recession/4210246/Adolf-Merckle-whatmade-thisGerman- billionaire-commit-suicide.html.

Danes, S. M. (2006), 'Tensions within family business-owning couples over time', Stress, Trauma, and Crisis, Vol 9, Nos 3 \& 4, pp $227-246$. Ercolani, M. (2008), Socio-Economic Patterns in UK Employees

Sickness Absence 1984-2004, Health at Work Working Paper, University of Aberdeen, Website: http:// www.abdn.ac.uk/haw/pubs.html.

Feltham, T. S., Feltham, G., and Barnett, J. J. (2005), 'The dependence of family businesses on a single decision-maker', Journal of Small Business Management, Vol 43, No 1, pp 1- 15.

Giebels, E., and Janssen, O. (2005), 'Conflict stress and reduced well-being at work: the buffering effect of third-party help', European Journal of Work \& Organizational Psychology, Vol 14, No 2, pp 137-155.

Glasscock, D. J., Rasmussen, K., Carstensen, O., and Hansen, O. N. (2006), 'Psychosocial factors and safety behaviour as predictors of accidental work injuries in farming', Work \& Stress, Vol 20, No 2, April-June, pp 173-189.

Goldsby, M. G., Kuratko, D. F., and Bishop, J. W. (2005), 'Entrepreneurship and fitness: an examination of rigorous exercise and goal attainment among small business owners', Journal of Small Business Management, Vol 43, No 1, pp 78-92.

Gómez-Mejia, L. R., Takacs Haynes, K., Nunez-Nickel, M., Jacobson, K., and Moyano-Fuentes, J. (2007), 'Socioemotional wealth and business risks in family-controlled firms: evidence from Spanish olive oil mills', Administrative Science Quarterly, Vol 52, No 1, pp $106-137$.

Greenhaus, J. H., and Beutell, N. J. (1985), 'Sources of conflict between work and family roles', Academy of Management Review, Vol 10, No $1, \mathrm{pp} 76-88$.

Grzywacz, J. G., Carlson, D. S., Kacmar, K. M., and Wayne, J. H. (2007), 'A multi-level perspective on the synergies between work and family', Journal of Occupational \& Organizational Psychology, Vol 80, No 4, pp 559-574.

Härenstam, A., Bejerot, E., Leijon, O., Schéele, P., and Waldenström, K. (2004), 'Multilevel analyses of organizational change and working conditions in public and private sector', European Journal of Work \& Organizational Psychology, Vol 13, No 3, pp 305-343. House, J. S., Landis, K. R., and Umberson, D. (1988), 'Social relationships and health', Science, Vol 241, No 4865, pp 540-545.

Jamal, M. (1997), 'Job stress, satisfaction, and mental health: an empirical examination of self-employed and non-selfemployed Canadians', Journal of Small Business Management, Vol 35, No 4, pp 48-57.

Kets de Vries, M., Carlock, R., and Florent-Treacy, E. (2007), Family Business on the Couch: A Psychological Perspective, John Wiley and Sons, Chichester.

Losada, M. (1999), 'The complex dynamics of high performance teams', Mathematical and Computer Modelling, Vol 30, No 9-10, pp 179-192.

McShane, S., and Von Glinow, M.-A. (2008), Organizational Behavior, 4 ed, McGraw-Hill, New York.

Miller, D., and Le Breton-Miller, I. (2006), 'Family governance and firm performance: agency, stewardship, and capabilities', Family Business Review, Vol 19, pp 73-87.

Miller, D., Le Breton-Miller, I., and Scholnick, B. (2008), 'Stewardship vs. stagnation: an empirical comparison of small family and non-family businesses', Journal of Management Studies, Vol 45, No 1, pp 51-78.

Nicholson, N. (2008), 'Evolutionary psychology and family business: a new synthesis for theory, research, and practice', Family Business Review, Vol 21, No 1, pp 103-118.

Nicholson, N., and Gordon, G. (2008), Family Wars: Classic Conflicts in Family Business and How to Deal With Them, Kogan Page, London.

Parslow, R. A., Jorm, A. F., Christensen, H., Rodgers, B., Strazdins, L., and D'Souza, R. M. (2004), 'The associations between work stress and mental health: a comparison of organizationally employed and self-employed workers', Work \& Stress, Vol 18, No 3, pp 231-244.

Pegula, S. M. (2004), 'Occupational fatalities: self-employed workers and wage and salary workers', Monthly Labor Review, March, pp 30-40.

Rauch, R., Ungery, J., and Rosenbuschz, N. (2007), 'The entrepreneur, entrepreneurial stress and long term survival: is there a causal link?' Frontiers of Entrepreneurship Research, Vol 27, No 4.

Seers, A., McGee, G. W., Serey, T. T., and Graen, G. B. (1983), 'The interaction of job stress and social support: a strong inference investigation', Academy of Management Journal, Vol 26, No 2, pp 273-284.

Sieber, S. D. (1974), 'Toward a theory of role accumulation', American Sociological Review, Vol 39, pp 567-578.

Smith, R., and McElwee, G. (2011), 'After the fall: developing a conceptual script based model of shame in narratives of entrepreneurs in crisis', International Journal of Sociology and Social Policy (forthcoming).

Taris, T. W., Geurts, S. A. E., Schaufeli, W. B., Blonk, R. W. B., and Lagerveld, S. E. (2008), 'All day and all of the night: the relative contribution of two dimensions of workaholism to wellbeing in self-employed worker', Work \& Stress, Vol 22, No 2, pp $153-165$.

Viswesvaran, C., Sanchez, J., and Fisher, J. (1999), 'The role of social support in the process of work stress: a meta-analysis', Journal of Vocational Behavior, Vol 54, No 2, pp 314-334.

Waldron, I., Weiss, C. C., and Hughes, M. E. (1998), 'Interacting effects of multiple roles on women's health', Journal of Health and Social Behavior, Vol 39, pp 216-236.

Yusuf, A. (1995), 'Critical success factors for small business: perceptions of South Pacific entrepreneurs', Journal of Small Business Management, Vol 33, No 1, pp 68-73. Zahra, S. A. (2005), 'Entrepreneurial risk taking in family firms', Family Business Review, Vol 18, No 1, pp 23-40.

Zahra, S. A., Hayton, J. C., Neubaum, D. O., Dibrell, C., and Craig, J. (2008), 'Culture of family commitment and strategic flexibility: the moderating effect of stewardship', Entrepreneurship Theory \& Practice, Vol 32, No 6, pp 1035-1054. 